\title{
Prevalence of Dental Caries among Slum Dwelling Children Aged 12-15 Years in Kolhapur, Maharashtra, India
}

\section{MOHSIN KHAN ${ }^{1}$, AFSHAN QURESHI ${ }^{2}$}

INTRODUCTION: Dental caries, is a global health burden which hampers the holistic health of an individual and leads to complications later in life.

AIM: To assess the dental caries status of children in slum-dwelling areas of Kolhapur district, Maharashtra, India.

MATERIALS AND METHODS: A cross-sectional, descriptive approach was conducted among 400 slum dwelling children aged 12-15 years using DMFT index, sterile instruments and ADA type III examinations. Descriptive statistics were applied using Microsoft excel. Data was then transferred into SPSS version 21.0 and the t-test (paired), Spearman's correlation and Odd's Ratio were applied to find significant associations, if any.

RESULTS: The prevalence of dental caries was found to be $69.0 \%$. Mean decay values were $3.02 \pm 1.22$, whereas the mean DMFT was 1.77 \pm 1.2. A significant difference was seen between caries free and children affected with caries $\left(\mathrm{p}=04^{*}, \mathrm{r}=0.78\right)$. It was also observed that males were 2.1 times more prone to have a higher DMFT as compared to females.

CONCLUSION: It is recommended that further studies be carried out among slum dwelling children of Kolhapur district, Maharashtra, India and specific dental education be imparted to them to improve their oral health.

KEYWORDS: Caries, Slums, DMFT Index, Odd's Ratio (OR)

\section{INTRODUCTION}

It is one of the great benefits of technology that it has given numerous advancements in the field of medicine and dentistry. From improving to one's life expectancy; to prevention of orofacial problems by better preventive, diagnostic and treatment techniques, the overall standard of one's health has considerably improved. However, despite these advancements, one of the most common dental disease to affect humans is dental caries; especially children.,

Such is the prevalence of dental caries among children, that it is considered to be the most common chronic disease of childhood (6-12 years) and causes pain, loss of self-esteem, absence from school, increased expenditure and is time consuming; especially if the caries progress and endodontic therapy is indicated. Hence it calls for greater care and attention towards maintaining the oral hygiene habits of these children. Frequent screening of the children (especially at schools) helps in identifying potential caries prone children and provide them with oral hygiene instruction; as well as prevent further progression of this disease in children already affected with caries.3,4
Screening of dental caries in children aged 12- 15 years is mostly indicated as once the child attains 12 years of age, all permanent teeth have erupted in the oral cavity (except third molars) and require attention so that the teeth are preserved for life. Once a child attains the age of 15 years, they have more or less established their dietary habits while the permanent teeth have been exposed to the oral environment for at least a period of 3-9 years; and hence a more meaningful assessment of and individual's caries status can be made. ${ }^{5,6}$ The World Health Organization in 1997 had also emphasized that there is often an increase in severity and prevalence of dental caries with an increase in one's age. ${ }^{7}$

In India, the prevalence of dental caries has shown a sharp increase over the following years. The increase has been reported from $55 \%$ (1940) to $72.5 \%$ (12 year old children) and 75.4\% (15 year old children) in the year $2003^{7}$ to $81.36 \%$ (2013). ${ }^{8}$ These results also vary from geographic locations as the beliefs and oral hygiene practices of people vary from one place to another. Therefore, it was necessary to assess the prevalence of dental caries 
among 12-15 year old slum dwelling school children in Kolhapur, Maharashtra, India.

\section{MATERIALS AND METHODS}

The present study adopted a cross-sectional, descriptive approach to assess the prevalence of dental caries among 12-15 year slum dwelling children of Kolhapur Region, Maharashtra, India and comprised of a total of 400 children. After obtaining ethical clearance, the parents were asked for their written consent (in Marathi/Hindi, to avoid language/comprehension barrier) before examining their children for the DMFT status of their children. The study was conducted from 1st July 2017 to 31st October 2017 and adopted a cluster based convenience sampling owing to the presence of slums in clusters in Kolhapur district, Maharashtra, India and efforts were made to ensure a maximum inclusion of children.

The examiners were duly calibrated by a trained examiner prior to the study on the DMFT index and their inter-examiner reliability value (kappa) was found as .63 (moderate). The examinations (ADA type III) were carried out after $2 \mathrm{pm}$ in broad daylight as most children return from their schools by this time. Instruments for examination were duly sterilized each day. Children who were available on the day of examination and those whose parents gave consent were included in the study. Children who were suffering from any systemic disease were excluded from the study.

Descriptive statistics were applied using Microsoft excel. Data was then transferred into SPSS version 21.0 and the t-test (paired), spearman's correlation as well as the gender based Odd's Ratio (OR) was applied to find significant associations, if any. The $\mathrm{p}$ (significance) value was set as significant when $\mathrm{p}$ was $\leq 0.05$.

\section{RESULTS}

The total study population is described in figure 1 . The study comprised to 400 children and it was observed that females formed a majority $(55.5 \%)$ as compared to their male counterparts.

Table 1 describes the overall prevalence of children with and without caries. It was observed that caries was seen in $276(69 \%)$ of the children while 124 (31\%) of the children were caries free. A significant difference was seen between caries free and children affected with caries. $\left(\mathrm{p}=04^{*}, \mathrm{r}=0.78\right)$

Table 2 describes the total prevalence of DMFT among the study subjects. The mean DMFT was found out to be $1.77 \pm 1.2$. The maximum number of mean decayed teeth was seen in males $(2.37 \pm 1.3)$, while missing teeth $(0.63 \pm 2.5)$ and filled teeth was seen among females $(1.76 \pm 1.12)$. A statistical significant difference was seen upon comparison of DMFT between both genders. It was also observed that males were 2.1 times more prone to have a higher DMFT as compared to females.

\section{DISCUSSION}

The results of the present study indicate a high prevalence of mean decayed teeth (3.02 \pm 1.22$)$, which demands immediate attention for providing specialist dental care among the slum dwelling children of Kolhapur, Maharashtra, India . These results are in disagreement when compared with the findings of Prabhakar J et al $(0.62 \pm 1.23)^{8}$, but in agreement with Ingle NA et al (2.92 \pm 1.97$).{ }^{9}$ Such is the impact of dental caries in children that WHO has ranked dental caries as the third most important non-communicable diseases that require worldwide attention for prevention and treatment. ${ }^{9}$

Upon comparison of the mean DMFT (1.77 \pm 1.2$)$, it is higher upon comparison with George $\mathrm{B}$ et al. $(0.65 \pm 0.005)^{10}$ and Verma $S$ et al. $\left(0.93^{ \pm 1.58}\right)^{11}$, in partial agreement with Veeraswamy $A$ et al. (average DMFT 2.03) ${ }^{12}$, and in disagreement with Shingare $\mathrm{P}$ et al. (mean DMFT 3.65) ${ }^{13}$ and Kundu $\mathrm{H}$ et al. (2.86 $\pm 7.48,15$ year olds in northern region of India). ${ }^{3}$ As mentioned earlier, these variations could be attributed to differences and beliefs according to geographic locations and different tooth brushing practices among people.

The study reported an overall prevalence of dental caries as $69 \%$, which is in disagreement to Hong CHL et al $(48.4 \%)^{14}$ and Rajesh SS et al(39.2\%). ${ }^{15}$ The findings of Veeraswamy A et al. $(61.4 \%)^{12}$ and Datta $P$ et al $(72 \%)^{16}$, however, agree with the results of the present study. On the contrary, higher prevalence of dental caries were observed by Shingare $\mathrm{P}$ et al $(80.92 \%)^{13}$ and Airen B et al. $(76.2 \%)^{17}$ who also document a high percentage of caries in their study subjects. These findings draw attention of the differences in knowledge, lack of motivation and no 
dental education being done in the specified regions of the studies conducted by the respective authors.

This study is prone to limitations, namely:

1. Selection bias due to convenience sampling used in the study as this study included children present on the day of the examination; also certain subject denied participation in the study which might have led to under/over- reporting of the DMFT scores. However, since the nature of this study was exploratory, we provide a baseline data and advise further studies on slum dwelling children of Kohlapur district, Maharashtra, India

\section{CONCLUSION}

It was found in the present study that slum dwelling children in Kohlapur district, Maharashtra, India are suffering from a high percentage dental caries and also have increased DMFT scores. Therefore, efforts should be directed towards providing urgent and specialized care to such children to secure their smiles for a lifetime.

\section{REFERENCES}

1. Shailee F, Sogi G M, Sharma K R, Nidhi P. Dental caries prevalence and treatment needs among 12and 15- Year old schoolchildren in Shimla city, Himachal Pradesh, India. Indian J Dent Res 2012;23:579-84.

2. Fejerskov O, Kidd E, Edwina AM. Dental caries: The disease and its clinical management. $2^{\text {nd }}$ ed. Wiley-Blackwell; 2008.

3. Kundu H, Patthi B, Singla A, Jankiram C, Jain S, Singh K. Dental Caries Scenario Among 5, 12 and 15Year-old Children in India- A Retrospective Analysis. Journal of Clinical and Diagnostic Research. JCDR 2015;9(7):ZEo1-ZEo5.

4. Campus G, Sacco, G, Cagetti M, Abati S. Changing trend of caries from 1989 to 2004 among 12-year old Sardinian children. Bio Med Central Public Health. 2007;7:28.

5. World Health Organization Oral Health Surveys, Basic Methods, 4th edition, 1997, http://www.who.int/oral health/publications/97892 $41548649 /$ en/. [Last accessed $12^{\text {th }}$ October, 2017]
6. Mahfouz M, Esaid AA. Dental Caries Prevalence among 12-15 Year Old Palestinian Children. International Scholarly Research Notices 2014, Article ID 785404, 4 pages.

7. National Oral Health Survey and Fluoride mapping 2002-2003. India: DCI Publication.

8. Prabakar J, John J, Srisakthi D. Prevalence of dental caries and treatment needs among school going children of Chandigarh. Indian J Dent Res 2016;27:547-52.

9. Ingle NA, Dubey HV, Kaur N, Gupta R. Prevalence of dental caries among school children of Bharatpur city, India. J Int Soc Prev Community Dent. 2014 ; 4(1) 52-5.

10. George B, Mulamoottil VM. Oral health status of 5, 12, and 15-year-old school children in Tiruvalla, Kerala, India. Dent Med Res 2015;3:15-9.

11. Verma S, Mallaiah P, Kadalur UG, Sharma R. Indian Dietary Habits in Relation to Dental Caries among 12-15 year old School Children in Bangalore City. Int J Oral Health Med Res 2016;3(1):44-47.

12. Veerasamy A, Kirk R, Gage J. Epidemiology of dental caries among adolescents in Tamil Nadu, India

13. Shingare P, Jogani V, Sevekar S, Patil S, Jha M. Dental caries prevalence among 3-to 14-year- old school children, Uran, Rigad District, Maharashtra. J Contemp Dent. 2012;2:11-14.

14. Hong CHL, Bagramian RA, Nainar SMH, Straffon LH, Shen L, Hsu CYS. High caries prevalence and risk factors among young preschool children in an urban community with water fluoridation. International Journal pediatric dentistry 2014;24(1):32-42.

15. Rajesh SS, Venkatesh P. Prevalence of dental caries among school-going children in South India. Int J Med Sci Public Health 2016;5:700-4

16. Datta P, Datta PP. Prevalence of Dental Caries among School Children in Sundarban, India. Epidemiol 2013;3:135.

17. Airen B, Dasar P, Nagarajappa S, Kumar S, Jain D, Warhekar S. Dentition status and treatment need in urban slum dwellers in Indore city, Central India. J Indian Assoc Public Health Dent 2014;12:163-6. 
Source of support: Nil, Conflict of interest: None declared

Cite this article as:

Khan M, Qureshi A. Prevalence of Dental Caries among Slum Dwelling Children Aged 12-15 Years in Kolhapur, Maharashtra, India. Int Healthcare Res J 2018;2(1):12-15.

doi: 10.26440/IHRJ/02_01/158

\section{AUTHOR AFFILIATIONS:}

1. Assistant Professor, Department of Public Health Dentistry, Tatyasaheb Kore Dental College and Research Centre, Kolhapur, Maharashtra

2. Post Graduate Student, Department of Oral and Maxillary Surgery, Rajasthan Dental College and Hospital, Jaipur

\section{Corresponding Author:}

Dr. Mohsin Khan

Assistant Professor

Department of Public Health Dentistry

Tatyasaheb Kore Dental College and Research Centre

Kolhapur, Maharashtra
For article enquiry/author contact details, e-mail at: manuscriptenquiry.ihrj@gmail.com

\section{LEGENDS}

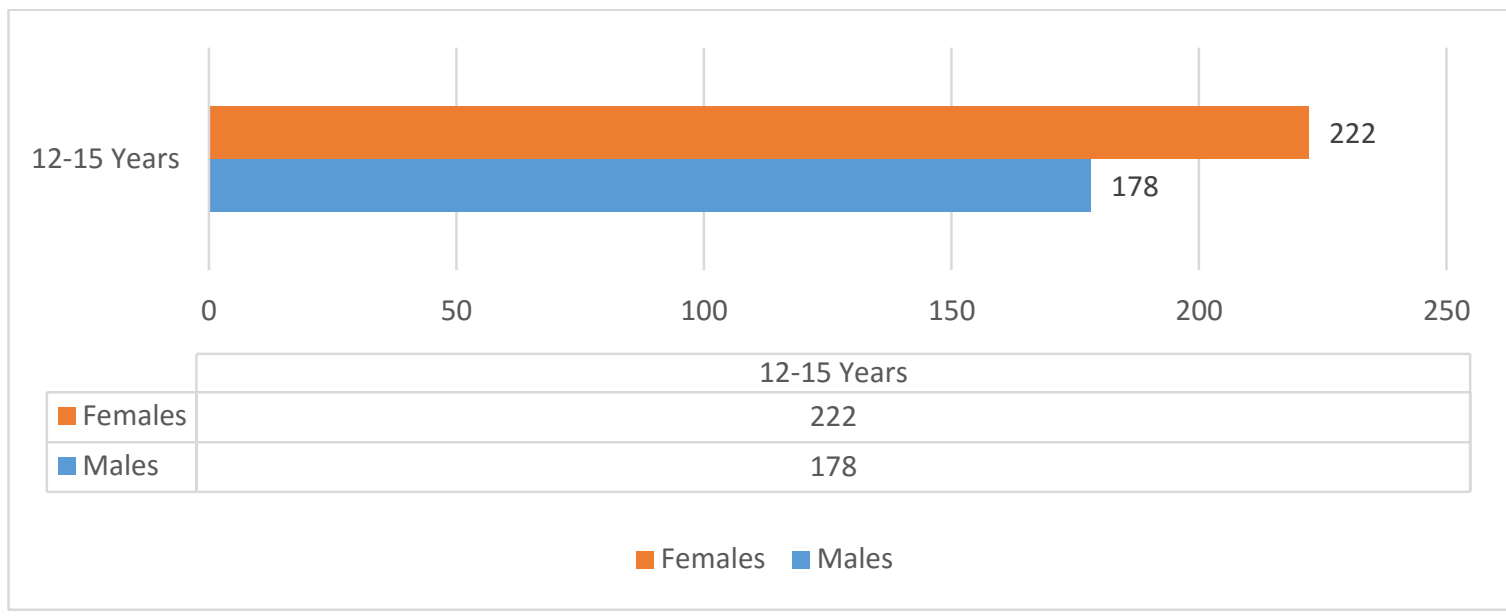

Figure 1. Distribution of the Study Subjects

\begin{tabular}{|c|c|c|c|c|}
\hline Characteristics & $\begin{array}{l}\text { Children with } \\
\text { caries }\end{array}$ & $\begin{array}{l}\text { Caries free } \\
\text { children }\end{array}$ & $\begin{array}{l}\text { t-test } \\
(\mathbf{p})\end{array}$ & $\begin{array}{c}\text { Spearman's } \\
\text { correlation } \\
(\mathbf{r})\end{array}$ \\
\hline Caries & $276(69 \%)$ & $124(31 \%)$ & $.04^{*}$ & .78 \\
\hline
\end{tabular}

Table 1. Prevalence of Dental Caries among the Study Subjects

\begin{tabular}{|c|c|c|c|c|c|}
\hline $\begin{array}{l}\text { Age Group (in } \\
\text { years) }\end{array}$ & Decayed Teeth & Missing Teeth & Filled Teeth & Mean DMFT & $\begin{array}{l}\text { Chi square/ } \\
\text { Odds Ratio }\end{array}$ \\
\hline $\begin{aligned} \text { 12-15 } & \\
\text { - } & \text { Males } \\
\bullet & \text { Females }\end{aligned}$ & $\begin{array}{c}3.02 \pm 1.22 \\
2.37 \pm 1.3 \\
1.79 \pm 1.14\end{array}$ & $\begin{array}{c}0.8 \pm 2.04 \\
0.24 \pm 1.36 \\
0.63 \pm 2.5\end{array}$ & $\begin{array}{l}1.5 \pm 1.81 \\
1.18 \pm 2.5 \\
1.76 \pm 1.12\end{array}$ & $\begin{array}{l}1.77 \pm 1.2 \\
1.94 \pm 1.0 \\
1.55 \pm 1.4\end{array}$ & $\begin{array}{c}0.04 \\
\mathrm{OR}=2.1\end{array}$ \\
\hline
\end{tabular}

Table 2. Mean DMFT Scores of the Study Population 